\title{
Conference on Workers' Culture, September, 1980
}

\section{Paul Buhle Heidi Gottfried}

The "First Annual Conference on Workers" Culture" which was held at the University of Michigan, developed a serious (if all too brief) dialogue about some very pressing questions. Is the concept of "Workers" Culture" valid in the US? Do workers share similar values and a world view which bind them as a class? Does the experience as workers shape their values, language (i.e., culture) and so on? Is job type a determinant in forming workers' consciousness? Is workers" identity articulated on- and off-the-job, and if so, when, how, why, and with whom? Participants ranging from academic labor historians and sociologists to labor movement functionaries and journalists mulled over the possibilities without anticipation of easy solutions. At times, however, they seemed to evoke an atmosphere where the questions could be properly framed.

The significance of the event, seen in the broadest terms, was several-fold. The effort is part of a revived campaign for labor education, reminiscent of Brookwood Labor School in the 1920 s when a movement similarly in retreat began to recuperate its own resources, seek out new allies and project a different public image (indeed, several of the participants vividly recalled Brookwood as their youthful contact with the ideals of labor). In this case, Labor and Industrial Relations activists situated under the shadow of the UAW's eroded empire thought to pull together allies who had known of each others' expertise but had never been together in a single room. Second, the conference program, and especially that aspect of actual performances (see below) pointed up the accelerating tempo of labor theatre, music and other ostensible entertainments springing up spontaneously in many parts of the country. Third, and for the most part negatively, the conference dramatized the problematic of academic knowledge put to the use of labor's purposes: did industrial folklorists and free-lance cultural critics have anything coherent to say to each other, let alone to a labor movement bordering upon intellectual bankruptcy?

Archie Green, outstanding labor folklorist, began the conference with an informal evening presentation on his own background in the Bay Area labor circuit 
of the early 1940s, his learning the particular clothes and talk deemed appropriate to a shipyard militant, and the implications Green could read back two score years later. Here and repeatedly throughout, Green's relating of the personal anecdote to the historical tendency proved critical. Like a wise uncle, Green kept tempers cool and priorities in order as far as possible.

The next day saw a number of illuminating discussions. Stanley Aronowitz probably provided the single most incisive political commentary on the difficulties workers' culture has faced in media-rich America and the consequent dilemmas for a coherent class self-identification. Bernice Johnson-Reagon characterized some of the special causes and traits of Black culture (most especially for women), insisting throughout the conference on an historical continuity in popular life that many whites could not perceive. Stan Weir spoke on the political connections between events in Gdansk and the rejection of American unions by many workers as the prime locus of labor culture. Paul Buhle applied the framework of ethnic radical-labor cultures to the broad questions of a self-knowledge and ultimate direction, which were not often apparent in the wider society.

Perhaps the greatest difficulties arose in an anthropologist/folklorist panel about "Occupational Culture." Did a construction workers" "community" exclusive of Blacks constitute a viable model for positive working class values? Did the careful description of informal and formal rules and norms among union railroad workers or non-union textile operatives have any inherent larger implications, or did they need to have such implications to be significant? Perhaps political differences had been masquerading as methodological differences, or then again perhaps the academic disciplines had become so absolute that discussion had become almost fruitless?

Sven Lindqvist, remarkable Swedish teacher and author, came as close as possible to reconciling the promise of labor's own history with the necessarily detailed observation of culture industry-by-industry and town-by-town. His monumental study, entitled in English Dig Where You Stand, builds upon the Swedish tradition of localized workers' cultural activities and moves on to the utopian conception of society transformed by self-knowledge and what the 1960 s movements called "participatory democracy." Could that signal effort meet the special problems of American blue-collar life, which as keen commentators from Barbara Garson to Brendan Sexton pointed out, had not realized itself through the existing institutions (like unions) or found meaningful alternatives? The answer could not be given unequivocally. Still, Lindqvist made a significant point, most especially for the academics: labor behavior is not to be recorded for the scholarly monograph alone and related in some far-off plan to the "public"; the process of understanding labor culture is one that must be at every point a two-way process, and with a goal larger than the "adjustment" of labor to its present circumstances.

Although the scholars found the concept of workers" culture problematic, the art presented in the second part of the conference demonstrated diverse expressions of workers which oppose mass culture. Much of this art expressed a culture of resistance and of intense class struggle; yet not all the art was explicitly class 
conscious. Workers not only consume culture imposed by elites, but also create their own forms whose content penetrates and challenges cultural hegemony. Workers" art often relies on the work community for its performance and the symbols and language used signify shared attitudes about the work process, the boss, the company, and so on.

The evening session began with a series of performances by worker-artisits. Larry Penn started the evening off by singing songs about trucking experiences. Bernice Johnson-Reagon, founder of Sweet Honey on the Rock, sang about the meaning and demeaning of work done by black women workers. One song dealt with her mother, a domestic worker who after eight hours working in a white family's home had to spend an additional eight hours slaving in her own. Her song asserted that any definition of work concerning black people would have to include the struggle for survival. Dottie Jones. UAW member, read a poem about the time clock's control over workers and another one chronicling her life history as a poor black woman facing the brutal reality of a pending plant closing. Many of her coworkers were in the audience and often verbally acknowledged their identification with the hardships mentioned, especially the welfare system looming in their future. Kenny Winfree, ACTWU member, sang some original songs telling the story of the struggle to organize a union in a textile mill down south. The other performances included the New York Street Theater Caravan performing skits and songs and Chuck Portz from The Labor Theater presenting a scene from Jack London.

The following day consisted of workshops focusing on different media. Participants met in workshops to discuss existing humanities programs at the state and national levels, union cultural projects and local labor history programs. Out of those workshops came these suggestions:

-Increase communication among artists, critics, and workers;

- Articulate connections between everyday life and art:

-Make cultural projects popular and informative, they should complement what is being done by workers themselves:

- Ensure ethnic and racial diversity in union cultural programs;

-Persuade television and other media to reflect the lives and concerns of workers.

That afternoon, panelists discussed images of blue collar workers in the media. Stan Weir, co-editor of Singlejack Press argued that workers were starved for positive images of themselves and thus outlets needed to be created for workers stories.

In addition, there was an exhibit of workers" art. "From Work io Leisure," displaying art that either depicts the work process or uses materials found in the workplace, for example:

- street scenes by Ralph Fasanella capturing the activity of a worhing class neighborhood and showing the collisions of the worlds of work and leisure. 
-a quilt fashioned from unclaimed garments in a laundry. The quilt-making became an important social activity for these women workers. It was a time to discuss work, the union and non-work related topics.

- metal sculptures created by a mig welder in-between jobs and a sheet metal journeyman from scrap metal.

-plastic sculptures shaped from excess molding plastic oozing out of an ejection molding machine in an auto parts plant.

- helmets decorated by steelworkers.

-paintings depicting assembly work by an autoworker.

- a detailed drawing of an empty work station, a result of a plant shut down.

-cartoons illustrating the introduction of robots and blundering bosses.

The conference also raised issues about the relationship of mass and workers" culture. "Mass culture is forgetting," stated Stanley Aronowitz. Many companies abide by this tenet. A worker at the conference related a story about a company's attempt to erase the memory of worker resistance. When an autoworker returned from his vacation, he found that his work station, which had been embellished with cartoons and drawings, had been restored to its original mass production appearance by the company. This company effectively cleansed the worker's identity from the workplace. Similarly, steel companies clean off decorations on helmets as proof that the company rules and isn't going to relinquish its firm control.

Art on-the-job is a form of worker resistance. Materials used in the creation of art are company property, and thus sacred, and if workers are caught using these materials, they are fired and even prosecuted for their transgression. Joking behavior, cartoons and narrative are other ways workers regain and assert some control over their labor or express the conflict of labor and capital; yet these are only brief moments of unalienated labor.

The conference had many outcomes: 1) initiated a network of workers, artists and scholars interested in workers culture, 2) established a newsletter on workers" culture, 3) produced a color video program documenting the art exhibit and performances by workers, and 4) began the process of planning for a model regional program on workers" culture. 